3. Obolentsev, Yu. B., Gnidin, Yu. B. (1990). Elektricheskoe osveschenie obschepromyishlennyih pomescheniy [Electric lighting general industrial premises]. Moscow, Russia: Energoatomizdat, 132.

4. Dzyundzyuk, B. V., Ivanov, V. G., Klimenko, V. M., Soldatov, A. V., Styitsenko, T. E., Tupunov, S. D., Filenko, N. A. (2006). Ohorona pratsi. ZbIrnik zadach [Occupational Health. Collection of problems]. Kharkiv: KhNURE, 243.
5. Ayzenberg, Yu. B. (Ed.) (1983) Spravochnaya kniga po svetotehnike [Handbook of Illumination]. Moscow: Energoatomizdat, 472.

6. Knorring, G. M., Fadin, I. M., Sidorov, V. N. (1992) Spravochnaya kniga dlya proektirovaniya elektricheskogo osvescheniya [Handbook for the design of electric lighting]. Moscow, Russia: Science, 117.

Дата надходження рукопису 11.09.2014

Дзюндзюк Борис Васильевич, доктор технических наук, профессор, заведующий кафедрой. кафедра «Охрана труда», Харьковский национальный университет радиоэлектроники, пр. Ленина, 14, г. Харьков, Украина, 61166

Копылов Геннадий Викторович, кандидат технических наук, старший преподаватель, кафедра «Охрана труда», Харьковский национальный университет радиоэлектроники, пр. Ленина, 14, г. Харьков, Украина, 61166

\author{
УДК 65.011.56 \\ DOI: $10.15587 / 2313-8416.2014 .27966$
}

\title{
ПРОГРАМНЕ ЗАБЕЗПЕЧЕННЯ ДЛЯ ПІДБОРУ ГАЗОВОГО ОБЛАДНАННЯ В IНТЕРНЕТ-МАГАЗИНІ
}

\author{
(C) І. В. Кузишин, Є. П. Павленко
}

Розглянута проблема розробки програмного забезпечення Інтернет-магазина компанії «Будівельник». Досліджені основні тендениії розробки жеb-додатків з використанням CMS-систем, а також проведено порівняння систем управління вмістом Jоотla і Opencart. Зроблено висновок, щчо кращим рішенням для створення Інтернет-магазину для приватного підприємства “Будівельник” буде вибір CMS OpenCart, яка дає більше можливостей в розширенні функціональності проектованої програми.

Ключові слова: Інтернет-магазин, система управління вмістом, Joоmla, Opencart, Open Server.

The problem of Internet-shop of company «Budivel'nik» software development is considered. The basic tendencies of development of web-appendixes are investigational with the use of the CMS-systems, and also comparison of control system by content of Joomla and Opencart is conducted. A conclusion is done, that by the best decision for creation the internet Shop for a private enterprise "Builder" will be choice of CMS Opencart, which gives more possibilities in expansion of functionality of the designed program

Keywords: Internet-shop, control system by content, Joomla, Opencart, Open Server

\section{1.Вступ}

Широке впровадження Web-оріснтованих інформаційних систем (IC) - об'єктивна необхідність, обумовлена ускладненням завдань управління, великими об'ємами інформації, що обробляються. Основною метою таких систем $є$ зберігання, забезпечення ефективного пошуку i передачі інформації по відповідних запитах. У найбільш поширених видах бізнесу основною проблемою завжди були об'єми інформації, які необхідно збирати, надійно зберігати і оперативно обробляти. Поява IC є відповіддю комп'ютерної індустрії на вимоги бізнесу. Залежно від конкретної області застосування IC можуть сильно розрізнятися по своїх функціях, архітектурі, реалізації.

Найбільшого розвитку зазнає зараз сфера комп'ютерних та інформаційних технологій. Проте широко розвиваються i iнші, наприклад, сфера будівництва. Типовим є використання інформаційних i комп'ютерних технологій у будівництві та інших секторах економіки. Для реалізації Інтернет-додатків, що підтримують рішення облікових задач в цій сфері, можна використовувати різні системи управління вмістом.

\section{2. Постановка задачі}

Приватне підприємство "Будівельник" займається продажею та монтажем систем опалення, водопостачання, каналізації і проводить їх монтаж. Компанія потребує сучасного Інтернет-магазину, який відкриє нові перспективи для розвитку i надасть змогу розширити сферу діяльності підприємства. Необхідна розробка спеціального програмного модуля для Інтернет-магазину, який полегшить користувачеві підбір та замовлення газового обладнання.

Таким чином підприємство намагається збільшити кількість своїх клієнтів, а також запровадити інноваційні методи підбору обладнання, які до того не використовувались.

Для приватних підприємств сфери будівництва, які існують на ринку досить давно, основною метою є утримання і збільшення клієнтів за рахунок надання кваліфікованих, доступних i корисних послуг. Однією із таких послуг є системи 
автоматичного обрахунку потужностей обладнання систем опалення. Дана система $є$ інноваційною i корисною для клієнтів. Впровадження даної webсистеми збільшить потік клієнтів до приватного підприємства.

Тому керівництво підприємства прийняло рішення про автоматизацію і створення відкритого сервісу системи обрахунку потужностей. Компанія планує надавати консультаційну допомогу користувачам через web-pecypc. Попередньо було обговорено, що будь-який користувач даного ресурсу може зв'язатися із консультантом, тому ресурс повинен бути інтуїтивно зрозумілим та простим для непрофесійних користувачів.

Розвиток інформаційних технологій, в тому числі і мов програмування, дозволяє вирішувати такі запитання. Необхідно було вибрати спеціальні продукти та засоби реалізації поставленої задачі.

Вхідною інформацією, яку клієнт магазину буде вводити на сайті, $є$ кількість зовнішніх стін приміщення, кількість вікон, кількість дверей, наявність даху, наявність підлоги, висота приміщення, ширина і довжина стін, мінімальна сезонна зовнішня температура, бажана внутрішня температура.

Розроблюваний Інтернет-додаток має розрахувати: для одного приміщення - максимальні тепловтрати приміщення, необхідну тепловіддачу радіатора для підтримання бажаної температури. Для жилого дому загалом: максимальні тепловтрати для дому, необхідну тепловіддачу для будинку, необхідну потужність обладнання.

\section{3. Літературний огляд}

У ряді джерел аналізуються переваги і недоліки CMS-систем. Зокрема, в [1] приведені наступні характеристики системи Јoomla: можливість розробки серйозного віртуального проекту, наділеного великими функціональними можливостями, система Joomla відома в мережі високим рівнем безпеки сайтів, які функціонують на ній. В [2] відмічається, що недоліком, притаманним всім безкоштовним системам, подібним Joomla, $\epsilon$ відсутність служби підтримки, але користувач отримує багато навчальних матеріалів і керівництв, а також форуми для обміну досвідом та вирішення виниклих проблем. В [3] вказано, що в Joomla $\epsilon$ зайвий програмний код в движку та шаблонах, що приводить до повільного завантаження сторінок сайту в порівнянні з іншими CMS.

В [4] відмічається, що система OpenCart призначається для створення Інтернет-магазину 3 повноцінним набором функцій та вимагає мінімальних зусиль при встановленні та налаштуванні, проста в адмініструванні, не має зайвих компонентів. Згідно [5], система OpenCart реалізує свою власну систему звітів: користувач може налаштовувати деталізовані звіти по замовленнях, поверненню товару, а також створювати списки найбільш реалізованих товарів. В [6] вказано, що один з істотних недоліків Opencart дублювання сторінок у великій кількості. Створені дублі відображаються по різних адресах, при цьому кожна сторінка індексується. Далі продубльовані сторінки «зводяться», а пошуковими системами визначається головна сторінка.

У зв'язку з цим виникає необхідність вибрати систему управління вмістом для розробки майбутнього Інтернет-магазину.

\section{4. Вибір системи управління вмістом}

Розробка Інтернет-магазину буде проводитись на базі системи управління вмістом - Content management system (CMS), яка буде реалізовувати весь основний функціонал майбутнього Інтернетмагазину.

Розглянемо найбільш поширені CMS, за допомогою яких можна буде виконати розробку програмного забезпечення - Joomla та OpenCart. Кожна 3 цих CMS $є$ вільно доступною та містить різноманітні інструменти для розробки Інтернетмагазину. I Joomla, i OpenCart дають можливість адміністрування і правильної організації клієнтської частини.

Найбільш популярною на сьогоднішній день $є$ система управління вмістом 3 відкритим кодом Joomla. Серед переваг CMS Joomla можна перерахувати такі [1]:

- орієнтованість на дизайнерів і розробників. Завдяки простий модифікації зовнішнього вигляду сайту можна швидко змінити зовнішній вигляд сайту до невпізнання. Це хороша можливість налаштувати його зовнішній вигляд;

- наявність додаткових компонентів, розширень, плагинів, інструментів, завдяки яким можна вбудувати в сайт додаткову функціональність. Ці компоненти практично не впливають на продуктивність сайту;

- привабливість готового продукту, постійні оновлення і підвищення якості і безпеки системи;

- вбудовані системи забезпечення безпеки контенту, схеми розміщення модулів та вбудовані системи шаблонів, присутня можливість самостійної зміни готових шаблонів чи вбудування своїх у вже існуючу систему, є розширена підтримка баз даних.

Недоліки CMS Joomla [2]:

- труднощі при переході на нову версію, коли можливе порушення деяких встановлених компонентів, причому можливо лише послідовне оновлення через проміжні версії;

- складність освоєння, відсутність служби підтримки.

Серед переваг CMS OpenCart можна перерахувати такі $[4,5]$ :

- установка Opencart проста, здійснюється вона копіюванням файлів движка на хостинг i прописуванням назви i пароля до бази даних, заздалегідь створеної на хостингу;

- наявність модулів i плагинів, які легко підключаються та завдяки яким істотно розширюється функціонал $\mathrm{i}$ зовнішній вигляд Інтернет-магазину;

- підтримка тим оформлення, які дозволяють управляти зовнішнім виглядом Інтернет-магазину. 
Оскільки теми розроблені на РНP, ї легко коректувати;

- у порівнянні з іншими CMS, у тому числі і з Joomla, вимагає менше ресурсів сервера і має вищу швидкість роботи, вбудований багатомовний режим, підтримка додатків із інших середовищ, легкість резервного копіювання i проведення статистичних аналізів, підтримка декількох валют і різних систем оплати.

\section{5. Структура розроблюваного Інтернет-}

При розробці проекту Інтернет-магазину використовувався локальний сервер - Open Server. Це портативний локальний WAMP / WNMP сервер, що має багатофункціональну керуючу програму i великий вибір підключених компонентів. Це повноцінний професійний інструмент, створений спеціально для веб-розробників.

Особливості Open Server, які вплинули на його вибір:

- докладний перегляд логів всіх компонентів в реальному часі;

- вибір НТТР , СУБД і РНР модулів в будьякому поєднанні; коробки ;

- підтримка SSL i кириличних доменів 3

- підтримка аліасів або по іншому доменних покажчиків, a так само зручна форма їх налаштування;

- доступ до доменів і швидкий доступ до шаблонів конфігурації модулів. $\begin{array}{ccc}\text { Перегляд } & \text { повідомлень } & \text { користувачів } \\ \text { розроблюваного } & \text { Інтернет-магазину } & \text { проводиться }\end{array}$ виключно адміністраторами ресурсу. На головній сторінці сайту знаходиться форма для входу, через яку користувач потрапляє у адміністративну часину. Лише адміністратори можуть керувати повідомленнями. доступу:

Передбачено адміністратора 3 двома рівнями

1.Адміністратор, який має права лише на перегляд повідомлень і можливість відповідати на них.

Адміністратор, який має можливість видаляти повідомлення або очищати ресурс взагалі. В загальному випадку структуру програми можна представити як відношення класів та методів реалізації функціоналу. Всі класи об’єднанні у файли 3 розширенням php, тому структуру програми можна представити як відношення файлів та взаємодію між ними. Вся програма ділиться на дві частини: частину користувача (клієнта) та частину адміністратора. Усі файли, які входять у дане відношення, безпосередньо взаємодіють між собою. Окрім цього, відбувається взаємодія між клієнтською та адміністративною частинами. Це відбувається завдяки зовнішнім файлам входу в адміністративну частину (login.php) та виходу з адміністративної частини в клієнтську (logout.php). На всі файли проекту адміністративної та клієнтської частини впливає файл каскадних таблицю стилю, який задає графічне оформлення для усього проекту.

2.Графічне зображення структури проекту представлено на рис. 1 .

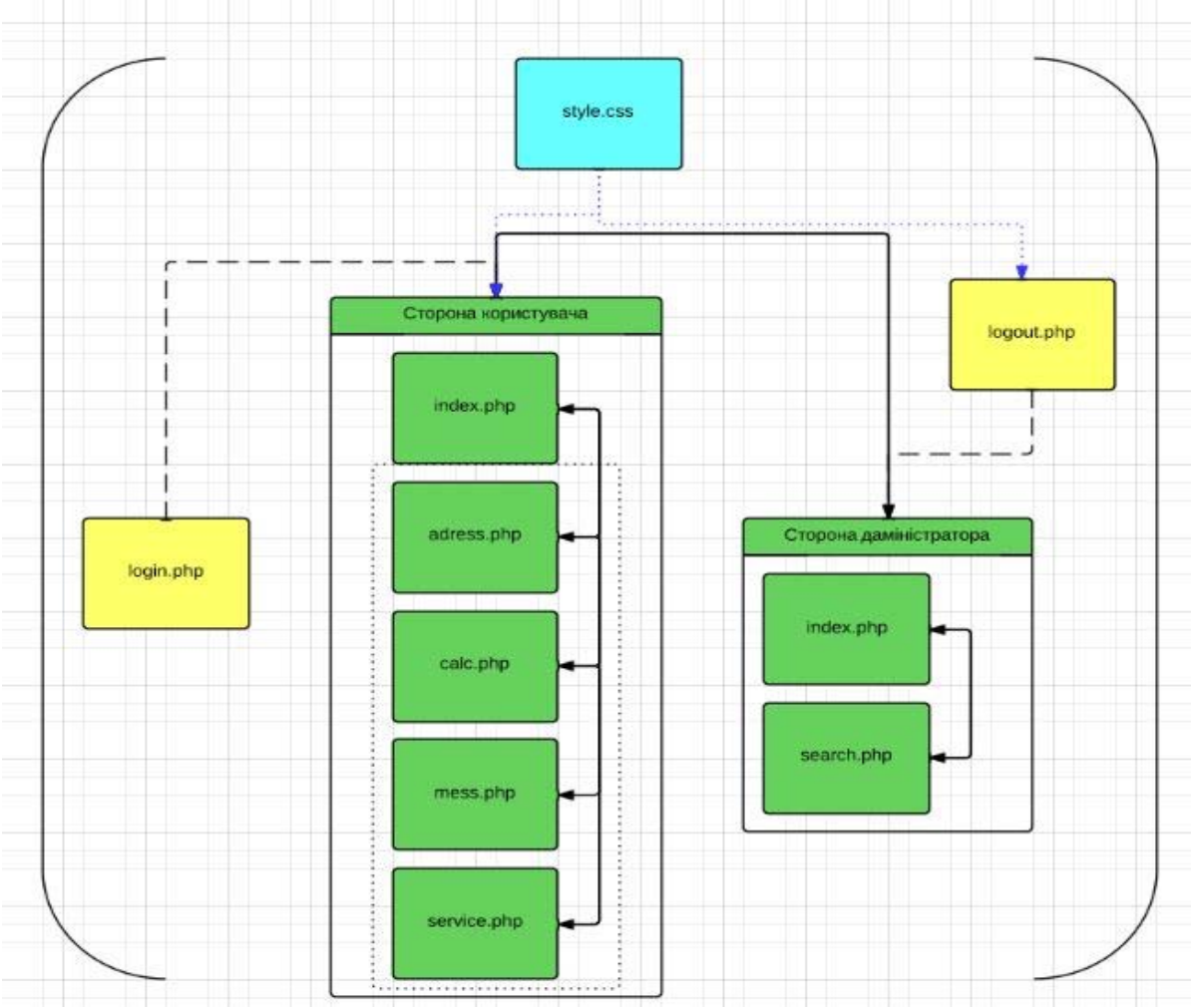

Рис. 1. Графічне представлення структури проекту 


\section{6. Висновки}

Виходячи з інформації про Joomla та OpenCart можна зробити висновок, що кращим рішенням для створення Інтернет-магазину для приватного підприємства "Будівельник" буде CMS OpenCart, яка дає більше можливостей в реалізації поставлених цілей, не вимагає великих ресурсів сервера i забезпечує доволі швидку роботу системи.

При розробці Інтернет-магазину також були застосовані локальний сервер - Open Server, мова програмування РНР та каскадні листи стилів.

\section{Литература}

1. Преимущества и недостатки «движка» Joomla :Top-Dohod.RU [Электронный pecypc] / Режим доступа: http:// top-dohod.ru/preimushhestva-i-nedostatkidvizhka-joomla/ - 15.09.2014 г. Загл. с экрана.

2. Преимущества и недостатки использования Joomla в качестве CMS для сайта. [Электронный ресурс] / Режим доступа: http://cmslist.ru/articles/preimuwestva_i_nedostatki_joomla/ 15.09.2014 г. Загл. с экрана.

3. Joomla!: достоинства и недостатки. [Электронный pecypc] / Режим доступа: http://seowords.org/raznoe/joomladostoinstva-i-nedostatki.html/ - 15.09.2014 г. Загл. с экрана.

4. Обзор Интернет-магазина OpenCart. [Электронный pecypc] / Режим доступа: http://webbuilding.com.ua/articles/opencart-advantagesdisadvantages/ - 15.09.2014 г. Загл. с экрана.
5. Преимущества и недостатки CMS OpenCart. [Электронный ресурс] / Режим доступа: http://joomstudio.com.ua/blog-studii/193-preimushchestva-inedostatki-cms-opencart.html - 15.09.2014 г. Загл. с экрана.

6. Создание онлайн-магазинов на Opencart: преимущества и недостатки. [Электронный ресурс] / Режим доступа: http://www.opencartmaster.ru/poleznayainformaciya/sozdanie-onlajn-magazinov-na-opencartpreimushhestva-i-nedostatki.html / - 15.09.2014 г. Загл. с экрана.

\section{References}

1. Advantages and lacks of «rendering-engine» Joomla: Top-Dohod.RU (2014) Available at: http:// topdohod.ru/preimushhestva-i-nedostatki-dvizhka-joomla/

2. Advantages and lacks of the use of Joomla as CMS for a site. (2014) Available at: http://cmslist.ru/articles/preimuwestva_i_nedostatki_joomla/

3. Joomla!: advantages and lacks. (2014) / Available at: $\mathrm{http}: / /$ seowords.org/raznoe/joomla-dostoinstva-inedostatki.html/

4. Review of Internet-shop OpenCart. (2014) / Available at: http://webbuilding.com.ua/articles/opencartadvantages-disadvantages/

5. Advantages and lacks CMS OpenCart. (2014) / Available at: http://joomstudio.com.ua/blog-studii/193preimushchestva-i-nedostatki-cms-opencart.html.

6. Creation of on-line-shops on Opencart: advantages and failings. (2014) / Available at: http://www.opencartmaster.ru/poleznaya-informaciya/sozdanieonlajn-magazinov-na-opencart-preimushhestva-inedostatki.html/

Рекомендовано до публікачії д-р техн. наук Хажмурадов М. А. Дата надходження рукопису 30.09.2014

Кузишин Іван Володимирович, кафедра інфораційно-управляючих систем, Харківський національний університет радіоелектроніки, пр. Леніна, 14, м. Харків, Україна, 61166

E-mail: kuzushtr@mail.ru

Павленко Свген Петрович, кандидат технічних наук, доцент, кафедра інфораційно-управляючих систем Харківський національний університет радіоелектроніки, пр. Леніна, 14, м. Харків, Україна, 61166 E-mail:evg-pavl@mail.ru

\title{
УДК 691.5
}

DOI: $10.15587 / 2313-8416.2014 .27999$

\section{БЕТОНИ НА ОСНОВІ ЛУЖНОГО ШЛАКОПОРТЛАНДЦЕМЕНТУ МОНОЛІТНОГО БУДІВНИЦТВА: ОСОБЛИВОСТІ СКЛАДІВ І ВЛАСТИВОСТЕЙ}

\author{
() В. І. Гоц, Р. Ф. Рунова, І. І. Руденко, О. В. Ластівка, Я. О. Говдун
}

Лиме при регулюванні особливостями порової структури бетону можливе управління його експлуатаційними властивостями, в т.ч морозостійкістю. Мета роботи - є виявлення взаємозв'язку капілярної пористості і морозостійкості бетону в залежності від композиційного складу лужного илакопортландцементу та хімічної природи добавок поверхнево-активних речовин (ПАР).

Ключеві слова: лужний шлакопортландиемент, важкий бетон, поверхнево-активна речовина, водопоглинання, капілярна пористість, морозостійкість.

To control performance properties of heavy concrete, including frost resistance, is possible only by means of regulation of its pore structure. The purpose of research was to identify relationship between parameters of porosity and frost resistance of concrete depending on composition of alkali activated slag Portland cement and chemical nature of surfactants.

Keywords: alkali activated slag Portland cement, heavy concrete, surface-active agent, capillary porosity, frost resistance. 